\title{
Bacterial Isolates from Endotracheal Aspirates and their Antimicrobial Resistance Pattern in Patients from Intensive Care Unit
}

\author{
ANDREEA LOREDANA GOLLI ${ }^{1}$, FLOAREA MIMI NITU2*, MARIA BALASOIU³, ROXANA MARIA NEMES4, \\ SORIN IOAN TUDORACHE ${ }^{5}$, BEATRICE MAHLER BOCA', MIH AI OLTEANU² \\ 'University of Medicine and Pharmacy Craiova, Department of Public Health, 2 Petru Rares Str, 200349, Craiova, Romania \\ 2 University of Medicine and Pharmacy Craiova, Department of Pneumology, 2 Petru Rares Str, 200349, Craiova, Romania \\ ${ }^{3}$ University of Medicine and Pharmacy Craiova, Laboratory Department, 2 Petru Rares Str, 200349, Craiova, Romania \\ ${ }^{4}$ Titu Maiorescu University, Faculty of Medicine, Department of Physiopathology, 22 Dambovnicului Str., 031593, Bucharest, \\ Romania \\ ${ }^{5}$ Titu Maiorescu University, Faculty of Medicine, Department of Anatomy, 22 Dambovnicului Str., 031593, Bucharest, Romania \\ ${ }^{6}$ Carol Davila University, Faculty of Medicine, Department of Pneumology, 8 Eroii Sanitari Blvd., 020021, Bucharest, Romania
}

\begin{abstract}
The emergence of multidrug-resistant (MDR) pathogens, especially for intensive care unit (ICU) patients is a serious threat to public health. To determine the frequency and antibiotic resistance pattern of bacterial pathogens isolated from tracheal aspirates of the patients admitted in ICU. The retrospective study included endotracheal aspirates from 734 patients admitted to the ICU, from J anuary to December 2017. The analysis of the resistance patterns for the action of the appropriate antibiotics was performed using Vitek 2 Compact system and diffusion method. A total of 985 bacterial isolates were obtained, of which 227 strains of Klebsiella spp. (23.04\%), followed by Nonfermenting Gram negative bacilli, other than Pseudomonas and Acinetobacter (NFB) (170-17.25\%), MRSA (134-13.60\%). Isolation rates indicates a higher value for male patients and elderly patients (over 65 years), statistically significant. High rates of MDR were found for Klebsiella spp. (70.04\%) and Pseudomonas aeruginosa (66.25\%) while almost all of the isolated NFB strains were MDR (98.82\%). The study revealed high rates of MDR pathogens in the majority of ICU isolates which may be due to unnecessary use of higher generations of antibiotics, use of mechanical devices, age, comorbidities, and can determine a higher rate of morbidity and mortality among these patients.
\end{abstract}

Keywords: multidrug resistance (MDR), intensive care unit, endotracheal aspirates

Antimicrobial resistance is a major world-wide problem in the intensive care unit (ICU), including in Romania, the emergence and spread of antimicrobial resistance (AMR) being now considered a global public health threat [1].

Hospital acquired infections (HAls) have been shown to occur about 5 to 10 times more in the patients admitted in ICUs, which are critically ill patients [2].

In the European Union, about 25000 patients die each year from infections caused byselected multidrug-resistant bacteria and the associated costs are estimated at about 1.5 billion euros per year [3].

According to the European Antimicrobial Resistance Surveillance Network (EARS- Net), Improving Patient Safety in Europe (IPSE) and ECDC data, Romania is one of the South-Eastern European countries with one of the highest prevalence rates of MDR pathogens. [4, 5] A worrying phenomenon in Romania is also the existence of the MDR-TB and XDR-TB cases in socio-economic conditions (malnutrition, agglomeration, stress), with the doubling of number of cases of XDR-TB in the last years $[6,7,8]$, including the cases of extrapulmonary tuberculosis which originates from the hematogenous metastatic affects developed during the prime TB infection period [9].

Therefore, the present study was designed to identify the bacterial profile and determine the antimicrobial resistance pattern of tracheal isolates among patients admitted to the ICU.

\section{Experimental part}

Materials and methods

The research is a retrospective study, which includes the determination of pathogens involved in respiratory infections of patients admitted to the intensive care unit (ICU) of Craiova Emergency Clinical County Hospital, Romania. Data were collected from January 2017 to December 2017 from the clinical pathology databases of the hospital, including culture sensitivity reports of the patients admitted to the ICU in the studied period. Samples included endotracheal tube aspirates from 734 patients of ICU. There were included in the study only those samples which were positive by culture.

The identification of the isolated strains on the clinical specimens received from ICU patients was carried out in the Hospital's Laboratory of Microbiology. The analyse of the resistance patterns for the action of the appropriate antibiotics was performed using Vitek 2 Compact system and diffusion method.

Antibiotics agents employed for susceptibility testing were amoxicillin-clavulanic acid $(20 / 10 \mu \mathrm{g})$, cefazolin (30 $\mu \mathrm{g})$, cefuroxime $(30 \mu \mathrm{g})$, ceftriaxone (30 $\mu \mathrm{g})$, cefotaxime $(30 \mu \mathrm{g})$ ceftazidime $(30 \mu \mathrm{g})$, cefepime $(30 \mu \mathrm{g})$, ciprofloxacin $(5 \mu \mathrm{g})$, teicoplanin $(30 \mu \mathrm{g})$, piperacillin-tazobactam $(30 \mu \mathrm{g})$, imipenem $(10 \mu \mathrm{g})$, meropenem $(10 \mu \mathrm{g})$, ertapenem $(10 \mu \mathrm{g})$, linezolid $(30 \mu \mathrm{g})$, tetracycline $(30 \mu \mathrm{g})$ penicillin $(10 \mu \mathrm{g})$, erythromycin $(15 \mu \mathrm{g})$, clindamycin $(2$ $\mu \mathrm{g})$, clarithromycin $(15 \mu \mathrm{g})$, doxycycline $(30 \mu \mathrm{g})$ and rifampicin $(5 \mu \mathrm{g})$. Interpretation was done according to Clinical Laboratory Standard Institute (CLSI) guidelines [10].

Information about gender and age of the patients, site of infection and antimicrobial resistance pattern were

\footnotetext{
* email: dr_nitumimi@yahoo.com, 0722491034
} 
collected from Hospital's Information System and from the available hospital records.

Data were entered and analysed using Microsoft Excel. Continuous variables like age are expressed as mean \pm STDEV. The pattern of micro-organisms and gender were analysed and expressed as percentages. The $\chi 2$ test was used for count data, and $p<0.05$ meant the difference was statistically significant.

\section{Results and discussions}

From J anuary to December 2017, there were analysed specimens of endotracheal aspirates collected from 734 patients hospitalized in ICU. The mean age of the patients was $59.49 \pm 22.39$ years, 301 women $(41.01 \%)$ and 433 men (58.99\%). Distribution of subjects by age group reflects the largest proportion of patients over 65 years (52.45\%) (table 1).

It is a retrospective study and the patients signed the informed consent for analysis and treatment.
A total of 985 bacterial isolates were obtained, excluding cases where it was more than one isolate of the same pathogen from the same patient. Among these, 712 isolates ( $72.28 \%)$ were Gram negative and 273 isolates (27.71\%) were Gram positive bacteria.

According to our study, the most common isolate of the Gram negative pathogens was Klebsiella spp. (31.88\%), followed by nonfermenting Gram negative bacilli, other than Pseudomonas and Acinetobacter (NFB) (23.87\%), Acinetobacter spp. (11.93\%), Pseudomonas aeruginosa (11.23\%), E.coli (10.67\%) and Proteus (8.00\%). while Methicillin-ResistantStaphylococcus Aureus (MRSA) were the first predominant Gram positive bacteria, accounting for $13,60 \%$ from all isolates.

Referring to the total number of samples collected by gender, isolation rates indicates a higher value for male patients, especially for NFB, E.coli, Klebsiella, Acinetobacter spp. Pseudomonas aeruginosa, CoNS-Coagulase-negative staphylococci (table 2).

Table 1

DISTRIBUTION OF STUDY SUBJ ECTS REGARDING GENDER AND AGE

\begin{tabular}{|c|c|c|c|c|}
\hline & & Age group & No & $\%$ \\
\hline \multirow{8}{*}{ Gender } & \multirow{4}{*}{ Female } & $0-18$ years & 30 & 14.92 \\
\hline & & $19-64$ years & 102 & 33.88 \\
\hline & & $\geq 65$ years & 169 & 56.14 \\
\hline & & total & 301 & 100 \\
\hline & \multirow{4}{*}{ Male } & $0-18$ years & 29 & 6.68 \\
\hline & & $19-64$ years & 189 & 43.54 \\
\hline & & $\geq 65$ years & 216 & 49.76 \\
\hline & & total & 433 & 100 \\
\hline \multirow{4}{*}{\multicolumn{2}{|c|}{ Total subjects }} & $0-18$ years & 59 & 8.03 \\
\hline & & 19-64 years & 291 & 39.64 \\
\hline & & $\geq 65$ years & 385 & 52.45 \\
\hline & & total & 734 & 100 \\
\hline
\end{tabular}

Table 2

DISTRIBUTION BY GENDER OF THE MICRO-ORGANISMS ISOLATED FROM ENDOTRACHEAL ASPIRATES FROM PATIENTS HOSPITALIZED IN ICU, COUNTY EMERGENCY CLINICAL HOSPITAL CRAIOVA, ROMANIA, BETWEEN J ANUARY-DECEMBER 2017

\begin{tabular}{|c|c|c|c|c|c|c|}
\hline \multirow{2}{*}{ Micro-0rganism } & \multicolumn{2}{|c|}{ Females } & \multicolumn{2}{c|}{ Males } & \multicolumn{2}{c|}{ Tota } \\
\cline { 2 - 7 } & $\mathrm{n}$ & $\%$ & $\mathrm{n}$ & $\%$ & $\mathrm{n}$ & $\%$ \\
\hline Acinetobacter & 31 & 36.47 & 54 & 63.53 & 85 & 100 \\
\hline NFB & 69 & 40.58 & 101 & 59.41 & 170 & 100 \\
\hline Citrobacter & 4 & 36.36 & 7 & 63.63 & 11 & 100 \\
\hline Enterobacter & 3 & 100 & 0 & 0 & 3 & 100 \\
\hline E.coli & 25 & 32.89 & 51 & 37.10 & 76 & 100 \\
\hline Haemophilus influenzae & 1 & 100 & 0 & 0 & 1 & 100 \\
\hline Klebsiella & 94 & 41.41 & 133 & 59.59 & 227 & 100 \\
\hline Proteus & 21 & 36.84 & 36 & 63.15 & 57 & 100 \\
\hline
\end{tabular}




\begin{tabular}{|c|c|c|c|c|c|c|}
\hline Pseudomonas & 33 & 41.25 & 47 & 58.75 & 80 & 100 \\
\hline Serratia & 0 & 0 & 1 & 100 & 1 & 100 \\
\hline CoNS & 35 & 35.71 & 63 & 64.28 & 98 & 100 \\
\hline S. aureus & 9 & 37.5 & 15 & 62.5 & 24 & 100 \\
\hline MRSA & 56 & 41.79 & 78 & 58.20 & 134 & 100 \\
\hline Streptococcus pnewmoniae & 7 & 41.17 & 10 & 58.82 & 17 & 100 \\
\hline Other Gram negative & 0 & 0 & 1 & 100 & 1 & 100 \\
\hline cocci & & & & & & 985 \\
\hline
\end{tabular}

Continuate

table 2

Table 3

DISTRIBUTION BY AGE GROUPS OF THE MOST COMMON MICRO-ORGANISMS ISOLATED FROM ENDOTRACHEAL ASPIRATES FROM PATIENTS HOSPITALIZED IN ICU, COUNTY EMERGENCY CLINICAL HOSPITAL CRAIOVA, ROMANIA, BETWEEN JANUARY-DECEMBER 2017

\begin{tabular}{|c|c|c|c|c|c|c|c|c|c|c|}
\hline \multirow{2}{*}{$\begin{array}{c}\text { Micro- } \\
\text { organism }\end{array}$} & \multicolumn{3}{|c|}{ Females } & \multicolumn{3}{|c|}{ Males } & \multicolumn{3}{|c|}{ Total } & \multirow[t]{2}{*}{$p$} \\
\hline & $\begin{array}{l}0-18 \\
\text { years }\end{array}$ & $\begin{array}{l}\text { 19- } \\
64 \\
\text { years }\end{array}$ & $\begin{array}{l}65+ \\
\text { years }\end{array}$ & $\begin{array}{l}18- \\
34 \\
\text { years }\end{array}$ & $\begin{array}{l}35- \\
64 \\
\text { years }\end{array}$ & $\begin{array}{l}65+ \\
\text { years }\end{array}$ & $\begin{array}{l}18- \\
34 \\
\text { years }\end{array}$ & $\begin{array}{l}35- \\
64 \\
\text { years }\end{array}$ & $\begin{array}{l}65+ \\
\text { years }\end{array}$ & \\
\hline Acinetobacter & 0 & 13 & 18 & 2 & 25 & 27 & 2 & 38 & 45 & $<0.001$ \\
\hline$N F B$ & 7 & 22 & 40 & 10 & 44 & 47 & 17 & 66 & 87 & $<0.001$ \\
\hline Klebsiella & 8 & 27 & 59 & 5 & 52 & 76 & 13 & 79 & 135 & $<0.001$ \\
\hline Proteus & 0 & 12 & 9 & 0 & 21 & 15 & 0 & 33 & 24 & $<0.001$ \\
\hline Pseudomonas & 4 & 12 & 17 & 2 & 26 & 19 & 6 & 38 & 36 & $<0.001$ \\
\hline E.coli & 2 & 6 & 17 & 3 & 17 & 31 & 5 & 23 & 48 & $<0.001$ \\
\hline$M R S A$ & 4 & 15 & 37 & 6 & 39 & 33 & 10 & 54 & 70 & $<0.001$ \\
\hline CoNS & 2 & 5 & 28 & 2 & 20 & 41 & 4 & 25 & 69 & $<0.001$ \\
\hline $\begin{array}{l}\text { Streptococcus } \\
\text { pneumoniae }\end{array}$ & 2 & 5 & 0 & 0 & 5 & 5 & 2 & 10 & 5 & $<0.001$ \\
\hline
\end{tabular}

In terms of germ distribution by age group, there was a larger number in the case of elderly patients (over 65 years), the difference being statistically significant $(p<0.001)$ (table 3). The highest percentage was registered for CoNS (70.40\%), followed by Pseudomonas aeruginosa (63.15\%) and NFB (59.47\%).

$42.10 \%$ of the Klebsiella spp. strains were isolated in patients over 65 years, with 13 cases being recorded in children $\leq 18$ years. Only 2 Acinetobacter strains were isolated in children (0-18 years), 6 of Pseudomonas aeruginosa and 10 of MRSA.

In our study we have analysed the percentage of multidrug-resistant (MDR) strains among the endotracheal aspirates from ICU patients, by taking into consideration resistance to at least three different antibiotic groups: aminoglycosides, cephalosporins, carbapenems, tetracyclines and fluoroquinolones. $85.88 \%$ from the Acinetobacter spp. strains were MDR. High rates of MDR were found for Klebsiellaspp. (70.04\%) and Pseudomonas aeruginosa $(66.25 \%)$ while almost all of the isolated NFB strains were MDR (98.82\%).

The antibiotic resistance rates of the isolates are summarized in tables 4-6. The combined resistance to multiple antimicrobial groups observed for Klebsiella spp. is consistent with European Centre for Disease Prevention and control (ECDC). The majority of infections caused by $K$. pneumoniae are healthcare-associated and the most common resistance phenotype was combined resistance to three key antimicrobial groups: fluoroquinolones, thirdgeneration cephalosporins and aminoglycosides [11].

Around $85 \%$ from the Klebsiella spp. strains isolated in our study were resistant to first generation cephalosporins, around $60 \%$ to second-generation, over $70 \%$ to thirdgeneration and over $65 \%$ to fourth-generation cephalosporins (table 4). Over $50 \%$ of the Klebsiella spp. strains were resistant to meropenem and ertapenem, and almost 


\begin{tabular}{|l|l|l|l|}
\hline $\begin{array}{c}\text { Antimicrobial } \\
\text { agent }\end{array}$ & $\begin{array}{c}\text { Klebsiella } \\
(227)\end{array}$ & $\begin{array}{l}\text { E.coli } \\
(76)\end{array}$ & $\begin{array}{l}\text { Proteus } \\
(57)\end{array}$ \\
\hline $\begin{array}{l}\text { Amoxicillin/clavulanic } \\
\text { acid }\end{array}$ & $70(30.83 \%)$ & $23(30.26 \%)$ & $15(26.31 \%)$ \\
\hline Ceftazidime & $162(71.36 \%)$ & $31(40.78 \%)$ & $49(85.96 \%)$ \\
\hline Ceftriaxone & $162(71.36 \%)$ & $33(43.42 \%)$ & $47(82.45 \%)$ \\
\hline Cefotaxime & $127(55.94 \%)$ & $21(27.63 \%)$ & $29(50.87 \%)$ \\
\hline Cefuroxime & $139(61.23 \%)$ & $25(32.89 \%)$ & $45(79.94 \%)$ \\
\hline Cefazolin & $194(85.46 \%)$ & $47(61.84 \%)$ & $50(87.71 \%)$ \\
\hline Cefepime & $152(66.96 \%)$ & $25(32.89 \%)$ & $39(68.42 \%)$ \\
\hline Imipenem & $64(28.19 \%)$ & $10(13.15 \%)$ & $17(29.82 \%)$ \\
\hline Ciprofloxacin & $102(44.93 \%)$ & $17(22.36 \%)$ & $32(56.14 \%)$ \\
\hline Meropenem & $140(61.67 \%)$ & $24(31.57 \%)$ & $31(54.38 \%)$ \\
\hline Piperacillin/tazobactam & $172(75.77 \%)$ & $36(47.36)$ & $37(64.91 \%)$ \\
\hline Ertapenem & $118(51.98 \%)$ & $14(18.42 \%)$ & $21(36.84 \%)$ \\
\hline
\end{tabular}

Table 4

ANTIMICROBIAL RESISTANCE PATTERN OF ENTEROBACTERIACEAE GNB (NUMBER AND PERCENTAGE)

\begin{tabular}{|l|l|l|l|}
\hline \multicolumn{1}{|c|}{$\begin{array}{c}\text { Antimicrobial } \\
\text { agent }\end{array}$} & \multicolumn{1}{|c|}{ MRSA(134) } & \multicolumn{1}{c|}{$\begin{array}{l}\text { CoNS } \\
(98)\end{array}$} & $\begin{array}{l}\text { Streptococcus } \\
\text { pneumoniae } \\
(17)\end{array}$ \\
\hline Ciprofloxacin & $90(7.16 \%)$ & $76(77.55 \%)$ & \multicolumn{1}{|c|}{} \\
\hline Clindamycin & $110(82.08 \%)$ & $83(84.69 \%)$ & $5(29.41 \%)$ \\
\hline Clarithromycin & $78(58.20 \%)$ & $31(31.63 \%)$ & $3(17.64 \%)$ \\
\hline Doxycycline & $57(42.53 \%)$ & $46(46.93 \%)$ & $9(52.94 \%)$ \\
\hline Erythromycin & $105(8.35 \%)$ & $77(78.57 \%)$ & $11(64.70 \%)$ \\
\hline Linezolid & $2(1.49 \%)$ & $3(3.06 \%)$ & $1(5.88 \%)$ \\
\hline Penicillin & $124(92.53 \%)$ & $95(96.33 \%)$ & $1(5.88 \%)$ \\
\hline Rifampicin & $69(51.49 \%)$ & $76(77.55 \%)$ & $5(29.41)$ \\
\hline Tetracycline & $102(76.11 \%)$ & $80(81.63 \%)$ & $10(58.82 \%)$ \\
\hline Teicoplanin & $19(14.17 \%)$ & $6(6.12 \%)$ & $13(76.47)$ \\
\hline Oxacillin & $108(80.59 \%)$ & $84(85.71 \%)$ & - \\
\hline \& - not tested & & & \\
\hline
\end{tabular}

Table 5

ANTIMICROBIAL RESISTANCE PATTERN OF GRAM POSITIVE COCCI (NUMBER AND PERCENTAGE) a third to imipenem, consistent to $C D C$ analysis which places Romania between the three countries with the highest carbapenems resistance [11]. Also $45 \%$ of the strains were resistant to ciprofloxacin and third to amoxicillin/clavulanic acid.

Around $30 \%$ of $E$. coli isolates were resistant to amoxicillin/clavulanic acid and meropenem and over $60 \%$ to first-generation cephalosporins.

In our research were identified $35.07 \%$ MDR MRSA strains in the Gram-positive group, in the conditions in which this pathogen has been the most important cause of antimicrobial-resistant healthcare-associated infections worldwide, with higher percentages in the southern and south-eastern parts of Europe [11].

A higher degree of resistance of MRSA was found to be against penicillin (92.53\%), clindamycin (82.08\%), erythromycin (78.35\%), tetracycline (76.11\%), oxacillin $(80,59 \%)$ and ciprofloxacin (67,16\%). Almost all MRSA strains (130 - 97.01\%), were susceptible to linezolid (table 5).

Over $80 \%$ from the isolated strains of coagulase-negative staphylococci (CoNS) were resistant to tetracycline, clindamycin and oxacillin, and over $95 \%$ to penicillin (table 5) Linezolid was the most effective drug among Gram positive isolates.

A high resistance to the cephalosporins (between 48$78 \%$ ), has been highlighted in the case of Pseudomonas aeruginosa strains. Half of the strains were resistant also to ciprofloxacin and over $60 \%$ to carbapenems (meropenem and ertapenem) (table 6).

A very high level of resistance was found for the tested strains of other nonfermenting Gram negative bacilli (other 


\begin{tabular}{|l|l|l|l|}
\hline \multicolumn{1}{|c|}{$\begin{array}{c}\text { Antimicrobial } \\
\text { agent }\end{array}$} & \multicolumn{1}{|c|}{$\begin{array}{c}\text { Acinetobacter spp. } \\
(85)\end{array}$} & \multicolumn{1}{|c|}{$\begin{array}{c}\text { Pseudomonas } \\
\text { spp. } \\
(80)\end{array}$} & \multicolumn{1}{|c|}{$\begin{array}{c}\text { Other NF- } \\
\text { GNB (170) }\end{array}$} \\
\hline $\begin{array}{l}\text { Amoxicillin/clavulanic } \\
\text { acid }\end{array}$ & $3(3.52 \%)$ & $29(36.25 \%)$ & $81(47.64 \%)$ \\
\hline Ceftazidime & $65(76.47 \%)$ & $56(70 \%)$ & $147(86.47 \%)$ \\
\hline Ceftriaxone & $39(45.88 \%)$ & $53(66.25 \%)$ & $152(89.41 \%)$ \\
\hline Cefotaxime & $79(92.94 \%)$ & $42(52.5 \%)$ & $128(75.29 \%)$ \\
\hline Cefuroxime & $2(2.35 \%)$ & $39(48.75 \%)$ & $121(71.17 \%)$ \\
\hline Cefazolin & $5(5.88 \%)$ & $63(78.75 \%)$ & $161(94.70 \%)$ \\
\hline Cefepime & $67(78.82 \%)$ & $55(68.75 \%)$ & $144(84.70 \%)$ \\
\hline Ertapenem & $4(4.70 \%)$ & $50(62.5 \%)$ & $146(85.88 \%)$ \\
\hline Imipenem & $66(77.64 \%)$ & $26(32.5 \%)$ & $103(60.58 \%)$ \\
\hline Ciprofloxacin & $69(81.17 \%)$ & $40(50 \%)$ & $75(44.11 \%)$ \\
\hline Meropenem & $68(80 \%)$ & $48(60 \%)$ & $147(86.47 \%)$ \\
\hline Piperacillin'tazobactam & $73(85.88 \%)$ & $49(61.25 \%)$ & $159(93.52 \%)$ \\
\hline Tetracycline & $2(2.35 \%$ & $16(20 \%)$ & $41(24.11 \%)$ \\
\hline
\end{tabular}

Table 6

ANTIMICROBIAL RESISTANCE PATTERN OF NON-FERMENTING GNB (NUMBER AND PERCENTAGE)
NF-GNB) (between 75-95\%), to all generations of cephalosporins, piperacillin/tazobactam, carbapenems. (table 6).

According to our study, for the Acinetobacter strains it was found a high resistance to the carbapenems (77-80\%) and to third and fourth-generation cephalosporins (cefotaxime - $92.94 \%$, ceftazidime - $76.47 \%$, cefepime $78.82 \%)$, and also to ciprofloxacin (81.17\%).

Over $80 \%$ of the Proteus strains were resistant to ceftazidime, ceftriaxone and cefuroxime, $68.42 \%$ to cefepime and almost $60 \%$ to ciprofloxacin.

Our study included patients with respiratory infections hospitalized in ICU, including all age groups, with the aim of highlighting the MDR strains.

The research revealed that the most common isolated pathogen was Klebsiella spp. (23.04\%), followed by NFBGlucose-nonfermenting Gram-negative bacilli (17.25\%) and MRSA (13.60\%). Also in other researchers' studies Klebsiella ranks first among isolated germs [12], while a similar percentage was also highlighted for this pathogen, but occupying the second place in the hierarchy of the most frequent pathogens involved in respiratoryinfections of patients hospitalized in ICU, after Acinetobacter spp. [13]. After other researchers, Staphylococcus aureus was the commonest isolate [14].

Predominantly Gram-negative germs, found in our study, is consistent with the results of other researchers $[13,15]$.

Although antibiotics are considered to be the most effective method of fighting against infections, their empirical, indiscriminate, prolonged, or incorrect usage contributes significantly to the selection of MDR strains $[16,17]$. Antimicrobial resistance (AMR) is a serious threat to public health and patient safety in Europe, leading to mounting healthcare costs, patient treatment failure, and deaths $[11,18,19]$.

Our study revealed that almost two-thirds of the strains of Klebsiella spp. are MDR, in the conditions in which, according to the European Antimicrobial Resistance Surveillance Network (EARS-Net), more than one third (34.5\%) of the Klebsiella pneumoniae isolates reported in 2016 were resistant to at least one of the antimicrobial groups under regular surveillance (fluoroquinolones, third generation cephalosporins, aminoglycosides and carbapenems).

In a research conducted by Radji et al [20], $K$. pneumoniae was also found to be multidrug resistant to the third generation cephalosporins and quinolone antibiotics. An increasing carbapenem resistance rate for Klebsiella, Acinetobacter and Pseudomonas was reported in their study by Akter et al [21].

A small percentage of $E$. coli strains have been carbapenem resistant, consistent with EARS-Net. The results are consistent with analyses from the European Centre for Disease Prevention and Control [11].

One-third of MRSA strains have been MDR, while both Coagulase-negative Staphylococci (CONS) and MRSA showed resistance to penicillin in almost all patients, consistent also with other findings [22]. MRSA remains a major cause of healthcare- associated infections worldwide, with higher percentages in the southern and south-eastern parts of Europe [23].

Our study revealed more than half of the Pseudomonas strains resistant to carbapenems and fluoroquinolones, outcomes consistent with other findings [2,24,25], and also to third and fourth-generation cephalosporins, despite the fact that there were significant decreases of the mean percentages for fluoroquinolone resistance, aminoglycoside resistance and carbapenem resistance during the period 2013 to 2016 [23],

In our study it was found also a very high level of resistance of Acinetobacter strains to the carbapenems and cephalosporins, which is consistent with the results from other studies $[2,26,27]$. $85.88 \%$ from the 
Acinetobacter spp. strains were MDR, which draws again attention to the fact that antimicrobial resistant Acinetobacter spp is a public health concern due to the severe limitation of treatment and infection control options [23].

Our study has identified a very high percentage of NFB strains resistant to all generations of cephalosporins, piperacillin/tazobactam, carbapenems, almost all strains being MDR. A worrying phenomenon in Romania is also the existence of the MDR-TB and XDR- TB cases in socioeconomic conditions (malnutrition, agglomeration, stress), with the doubling of number of cases of XDR-TB in the last years, including the cases of extrapulmonary tuberculosis which originates from the hematogenous metastatic affects developed during the prime TB infection period [2830]

All these observations are in line with the results of other studies we have conducted to identify germs involved in the production of infections in patients hospitalized in ICU. $[31,32]$.

\section{Conclusions}

The study revealed that lower respiratory tractinfections in ICU hospitalized patients are increasing and the majority of isolates belong to MDR category. Regardless of the age category, males were more affected by Klebsiella, NFB, Acinetobacter, Pseudomonas, MRSA in terms of bacterial isolates, compared with females.

To prevent the proliferation of MDR strains, a strict hospital infection control policy and the surveillance of antibiotic prescription are necessary.

\section{References}

1.NUNEZ M, NAVARRO MD, PALOMO V, RAJ ENDRAN NB, DEL TORO MD, VOSS A, SHARLAND M, SIFAKIS F, TACCONELLI E, RODRIGUEZBANO J. Clinical Microbiology and Infection; 24, 2018 p:105-109. 2.MOOLCHANDANI K, SASTRY AS, DEEPASHREE R, SISTLA S, HARISH BN, MANDAL J. Journal of Clinical and Diagnostic Research; 11, no. 2, 2017, p : DC01-DC07.

3.LEUNG E, WEIL DE, Raviglione M, Nakatania H. Bull World Health Organ; 89, 2011,p:390-392.

4.LICKER M, MOLDOVAN R, HOGEA E, MUNTEAN D, HORHAT F, DANDESC D, MACARIE C, CRÃCIUNESCU M, BADIOIU L.Farmacia, 65, no. 6, 2017, p:929-933

5.NITU NITU MF,OLTEANU M, STREBA CT, JIMBOREAN G, POSTOLACHE P, MAN MA, TROFOR AC, NEMES RM, DRAGONU L, OLTEANU M, Romanian Journal of Morphology and Embryology, 58, no. 2, 2017, p:385-392.

6.GOLLI AL, NITU MF, TURCU F, POPESCU M, CIOBANU MITRACHE L, OLTEANU M., Int J Tuberc Lung Dis, 23, no.2, 2019, p:226-231

7.NITU, FM., OLTEANU, M., STREBA CT. etal., Rom J Morphol Embryol., 58, no. 2, 2017, p:385-392.

8.IBRAIM, E., CIORAN, N., POPESCU, N., FURTUNESCU, FL., European Respiratory J ournal, 40 no.56 2012, p: 3346

9.0LTEANU M, NIU M, GOLLI A. Rom J Morphol Embryol, 53, no.3, 2012, p:835-840
10.PATEL JB, WEINSTEIN MP, ELIOPOULOS GM, JENKINS SG, LEWIS JS, LIMBAGO B, MATHERS AJ, MAZZULLI T, PATEL R, RICHTER SS, SATLIN M, SWENSON J M, TRACZEW SKI MM, TURNIDGE JD, ZIMMER BL. CLSI. Performance Standards for Antimicrobial Susceptibility Testing; 27th Edition, Clinical and Laboratory Standards Institute.

11.*** Antimicrobial resistance surveillance in Europe, SURVEILLANCE REPORT. http://www.ecdc.europa.eu, 2015 [accessed June 2018].

12.GHOSH B, GHOSH K, ROY A, PAL D, GHOSH A, MONDAL K. Int J of Recent Trends in Science and Technology:;11, 2014, p:245-248.

13.ASHIS KS, SUMAN N, PAYODHI D. International Journal of Contemporary Medical Research; 3, no.6, 2016, p:1775-1781.

14.AMINI M, JAVANMARD A, DAVATI A, AZIMI G. Iran J Pathol.;4, 2009, p:123-127.

15.RAHBAR M, HAJ IA M., InfectControl Hosp Epidemiol.;27, 2006,p:884885.

16.LAXMINARAYAN R, DUSE A, WATTAL C, ZAIDI AK, WERTHEIM HF, SUMPRADIT N, VLIEGHE E, HARA GL, GOULD IM, GOOSSENS H. et al. Lancet Infect. Dis., 13, 2013,p: 1057-1098.

17.LLOR C, BJ ERRUM L., Ther. Adv. Drug Saf., 5, 2014,p: 229-241.

18.DUCEAC, L.D., TARCA, E., CIUHODARU, M.I., TANTU, M.M., DAMIR,

D., GLOD, M., LUCA, A.C., Rev. Chim. (Bucharest), 70, no.1, 2019, p:199-201

19.GOLLI, AL., NITU, F.M., BALASOIU, M., LUNGU, M.A., DRAGOMIRESCU, C.C., OLTEANU, M., NEMES, R.M., TANTU, M.M., OLTEANU, M., Rev. CHim. (Bucharest), 70, no. 5, 2019, p. 1778-1783 20.RADJ I M, FAUZIAH S, ARIBINUK N. Asian Pacific J ournal of Tropical Biomedicine; 1 , no.1, 2011, p:39-42.

21.AKTER T, MURSHED M, BEGUM T, NAHAR K, DUZA SS, SHAHNAZS. Bangladesh J Med Microbiol, 8 , no.1, 2014, p: 7-11.

22.BHATIA A, KALRA J, KOHLI S, KAKATI B, KAUSHIK R. International J ournal of Basic \& Clinical Pharmacology, 7 , no.5, 2018, p:906-911.

23.*** Antimicrobial resistance surveillance in Europe, SURVEILLANCE REPORT, 2016, http://www.ecdc.europa.eu, [accessed June 2018].

24.GILL JS, ARORA S, KHANNA SP, HARI KUMAR KVS. J ournal of Global Infectious Diseases; 8, no.4, 2016, p: 155-159.

25.AXENTE, C., MUNTEAN, D., BADITOIU, L., MOLDOVAN, R., HOGEA, E., HORHAT, F., BEDREAG, O., SANDESC, D., DUGAESESCU, D., VOICU, M., DUMITRASCU, V., LICKER, M., Rev. Chim.(Bucharest), 68, no.6, 2017, p.1223-1226.

26.STRATCHOUNSKIL LS, KOZLOV RS, RECHEDKO GK, STETSIOUKL OU, CHAVRIKOVA El. Clin Microbiol Infect; 4, 1998, p: 497-507

27.AL BSHABSHE A, JOSEPH MRP, AL HUSSEIN A, HAIMOUR W, HAMID ME. Asian Pacific J ournal of Tropical Medicine; 9 , no.9, 2016, p:903908.

28.NEMES, RM., IANOSI ES., POP CS., POSTOLACHE P., STREBA T., OLTEANU M., GOLLI AL., OLTEANU M., NITU MF. Romanian Journal of Morphology and Embryology, 56, no. 2, 2015, p: 521-525.

29.MAN, MA., NITU MF., STRAMBU, L., FLORESCU, C., STREBA, CT., TROFOR, AC. Romanian J ournal of Morphology and Embryology, $\mathbf{5 7}$, no.1, 2016, p: 237-242

30.MAN, MA., ARGHIR, OC., MAN, S., STREBA, CT., OLTEANU, M., NITU, M., Romanian Journal of Morphology and Embryology, 55, no. 2, 2014, p:453-457

31.GOLLI, A.L, NITU, M.F, BALASOIU, M., LUNGU, M.A., OLTEANU, MADALINA, NEMES, R.M., FORTOFOIU, M., RUSU, E., OLTEANU, M., Rev. Chim.(Bucharest); 69, no.12, 2018, p.3433- 3438.

32.GOLLI, AL., NITU, M.F., BALASOIU, M., LUNGU, M.A., DRAGOMIRESCU, C.C., OLTEANU, M., NEMES RM, TANTU, M.M., OLTEANU, M., Rev. Chim. (Bucharest), 70, no.5, 2019, p.1778-1783

Manuscript received: 5.06 .2019 